\title{
INTERCULTURAL EXCHANGES IN A FOREIGN LANGUAGE DIMENSION IN RETROSPECT: A CORPUS ANALYSIS OF RESPONDENTS' PERCEPTIONS
}

\author{
Alcina Sousa \\ University of Madeira, Portugal
}

\begin{abstract}
This paper aims at reassessing some evidence on EFL learners'/undergraduates' perceptions on intercultural exchanges in/between a foreign language (FL) and mother tongue (L1), grounded on an empirical research undertaken in Madeira (1998-1999). This involved a representative number of $12^{\text {th }}$ form Humanities students (secondary school) and first- and second-year undergraduates taking English (Joint Honours) then. The process of interpretation of respondents' output borrows from a cross-disciplinary framework (Traugott and Pratt 1980, Woods et al. 1996) in a postmodern paradigm of applied research to which Foucault (1972), Bakhtin ([1935] 1990) and Barthes (1975) have left their contribution, while resorting to corpus analysis (Biber et al. 1998, Sinclair 2004). The analysis of some core lexemes, like text, knowledge, and meaning, and other collocations were singled out which have allowed for the identification of recurrent patterns (for example, "informative texts", "descriptive texts" and "cultural texts") and the meaning potential associated with them.

Among the issues under scrutiny, there will be a focus on both language/culture interface underpinning FL teaching/learning standards, and informants' affective identification with a foreign language/culture reinforced by the so-called representative cultural artefacts (Byram 1988: 41). In the discussion about the dialogic encounter of mother tongue/foreign languages, issues of culture, identity, discursive communities and practices will come to the fore.
\end{abstract}

Key words: cultural awareness, globalisation, "same”/“the other”, language and cultural identity(ies), discursive practices, “third culture”.

None of us can simply choose another language, as though we could completely abandon our previous history and freely opt for another one... The zone we now inhabit is open, full of gaps: an excess that is irreducible to a single centre, origin or point of view. In these intervals, and the punctuation of our lives, other stories, languages and identities can also be heard, encountered, experienced.

Iain Chambers (1995: 24) 


\section{Introduction}

At a time when individuals are required competence in (Micklos 2001: 5, Byram and Grundy 2003) "new literacies" in a technological world (Ong 1993), this paper suggests a renewed and refreshing view (Micklos 2001: 5) on an ever-problem posing issue as is the encounter between mother tongue (L1) and foreign language(s) (FL) promoted in the teaching/learning context as a way-in to wider communicative contexts in the global world. For the attainment of this purpose some evidence on EFL learners'/undergraduates' perceptions on intercultural exchanges in a foreign language dimension will be discussed, grounded on an empirical research undertaken 1 on Madeira Island in 1998. This involved a representative number of informants: 12th form Humanities students $(n=197)$ and first- and second-year undergraduates $(n=57)$ taking English - Joint Honours- at the University of Madeira. Their response to a questionnaire on reading habits, purpose, strategies and text types in English as a foreign language2 has offered renewed insights 3 on the sort of implications of FL instruction on subjects' perceptions on the language/culture interaction. Similarly, this inquiry, of ethnographic nature, made it possible to unearth relevant aspects associated with the sort of attitude shared by individuals of a linguistic community, i.e., the Portuguese one, towards mother tongue and the target language community. Therefore, and for readability issues, the analysis of corpora is sometimes complemented with subjects' output (in concordance lines), or encodings of their response to open-ended questions.

The process of interpretation of respondents' output borrows from a crossdisciplinary framework (Traugott and Pratt 1980, Woods et al. 1996) in a postmodern research paradigm to which Foucault (1972), Bakhtin ([1935] 1990) and Barthes (1977) have left their contribution, while resorting to corpus analysis ${ }^{4}$

${ }^{1}$ This aimed at accounting for a major problem, namely Humanities freshman’s reluctant attitude to reading on the whole, with a special focus on literary texts, together with a poor critical and creative response to literature which was confirmed by resorting to qualitative and quantitative analyses (i.e., corpus analysis, inferential and exploratory statistic texts, among other).

${ }^{2}$ The content of the questionnaire addressed the issues at hand involving the informants with questioning, prompting and reflecting, by means of open-ended questions. "Giving reasons" (also making part of item-dependent, open-ended questions/answers) followed short answers and multiple choice items.

${ }^{3}$ This research ranging the ethnographic nature attempts to uncover some relevant aspects associated with Humanities freshman's differing degrees of engagement with the reading activity in an EFL context, from reluctance (only reading for mandatory reasons) to enjoyment. Bridging this diversity in terms of linguistic, cultural, social and varied levels of achievement, implies a reflection on theory, research and above all what real subjects, learners and practitioners (Hinson 2000) in a concrete situation know, think and do about reading.

${ }^{4}$ According to Sampson and McCarthy (2004: 1), corpus is "a collection of specimens of a language as used in real life, in speech or writing, selected as a sizeable 'fair sample' of the language as a whole or of some linguistic genre”, comprising a useful source of evidence for language research. As such, contemporary corpus-based approaches (Baker 2006) rely very heavily on computer tools, since very many research techniques and methods make use of: (1) electronically retrieved texts/corpora; and (2) concordancers (for example Word Smith Tools, Mono Conc, Concapp, among 
(Biber et al. 1998, Sinclair 2000). A corpus-based approach ${ }^{5}$, drawing on respondents' output retrieved into two different files $\left(12^{\text {th }}\right.$ formers' and freshman's corpora) for comparative analysis ${ }^{6}$, has shed some light on the language/culture interface underpinning FL teaching/learning standards.

While investigating the use of language features in such a small corpus, in a total of 43784 words in the two databases (32394 words - $12^{\text {th }}$ formers' corpus; 11390 words - undergraduates' corpus), the inclusion and analysis of unexpected occurrences of lexical items (for example, "documents", "dialogues" and "language/s"), "only moderately common or rare words", depended on the interrelated "topics represented in the texts of the corpus". Following Barthes's contention ([1975]1994: 42), these entail "an unconstrained word that claims consistency of its own insistence" opposing expected "stereotypes", given the problem at hand, if related to any lexico-semantic field. For example, and bearing in mind the underlying issues associated with FL speakers' positioning towards mother tongue and foreign language, like "otherness", "identity" and/or "exclusion", lexical items like "other"7 and "our" are included in this analysis because of their repeated occurrence in concordance lines on the nodes "language/s", "Portuguese" and "English". In fact, concordance data may shed some light both on "the conceptual meaning of words and the connotational significance of lexis”, advances Partington (1998: 65).

Assuming that the subject-matter of the questionnaires revolved around respondents' perceptions on reading in English, several lexical items might be predicted either because of the domain and literature in the field (that is, reading in education and foreign language instruction), or because of acquaintance with EFL

other). In addition, contend the scholars "only electronic processing allows one to search for some form or structure of interest in a large collection of language samples with confidence that one has extracted all relevant instances". It also allows for quantification and comparative analysis of the (Partington 1998: 65) "conceptual meaning of words and the connotational significance of lexis" in a corpus and corpora.

${ }^{5}$ Light and Cox (2001: 232) enlighten some of the benefits of taking up a wide variety of methods and techniques likely to shed light on "student experiences and/or conceptions of learning within the practitioner's particular teaching and learning situation". To follow Biber et al. (1998: 246):

A corpus is not simply a collection of texts. Rather, a corpus seeks to represent a language or some part of a language. The appropriate design for a corpus therefore depends upon what it is meant to represent. The representativeness of the corpus, in turn, determines the kinds of research questions that can be addressed and the generalizability of the results of the research. Thus, whether you are designing a corpus of your own, choosing a corpus to use in a study, or reading others' corpus-based work, issues of representativeness in corpus design are crucial.

6 Before both texts / corpora (i.e., secondary school respondents' database and undergraduates' database) were input from two different files, previously formatted into RTF, subjects' output to open-ended items was sorted out and their identification codes attached, that is class / teachers' code and number. Yet, informants' response to closed items (for example, "polar items" - Widdowson 1996: 95) and the instructions in the "Reading Evaluation Questionnaire" were discarded.

${ }^{7}$ The semantic density possibly uncovered by the binary "same” and "other" was expected to become highlighting, yet the analysis of the collocational meaning of "same" did not offer enough evidence for the problematic at hand. 
speakers' current spoken and written production (poor syntax and mechanical accuracy). Still, there are items with association with others, i.e., their collocates, as offered in concordance samples ${ }^{8}$, which acquire (Partington 1998: 66) "a favourable or unfavourable connotation", or semantic prosody (borrowing from Sinclair 1987, 1991, 2004). These "regular patterns of collocation between words", adds Louw (1993, in Sampson and McCarthy 2004: 229), could not be "predicted on the basis of their 'dictionary meanings'” [author's emphasis]. In so doing, other complementary matters, though beyond the scope of this paper, might be brought to the fore: context and culture in language teaching and learning; foreign language teaching/learning; clashing/overlapping identities among participants of a linguistic community, i.e., Portuguese, living in/between European languages/cultures, and speaking a foreign language for broader communicative purposes (Melo et al. 2006); language standards, competencies and skills, to ensure parity and promote communication and understanding among individuals in the European sphere and worldwide ${ }^{9}$, among other. In this respect, Byram rightly states (1988: 41):

Language in use by particular speakers is constantly referring beyond itself irrespective of the intentions of the speaker,... even in the most sterile environment of the foreign language class. The meanings of a particular social grouping and the analysis of those meanings... involves the analysis and comprehension of that culture. [abridged Mine]

\section{Mother Tongue - Foreign Language: Some Considerations}

Choosing another language/world view to communicate globally, to draw on Chambers's introductory quote to this paper, and English is now the master code, or the so-called lingua franca (Jenkins 2008, James 2008), presupposes that individuals are aware of the multiple clashes encountered and experienced in everyday communication. In the process, the multifaceted FL teaching/learning paradigm, as perceived by Byram and Grundy (2003: 1), "has developed in many directions and with considerable vigour in the last 10 to 15 years". It is marked by shifts from functional to communicative approaches, and "the origins lie partly within theory and practice of language teaching, and partly in response to the recognition of the social

${ }^{8}$ Authenticity in corpus design (among other scientific criteria like validity, reliability, replicability and objectivity) and in empirical research demands (Biber et al. 1998: 250) "certain practical considerations, such as ensuring consistent transcription of... data". Consequently, informants' written output was transcribed without any changes whatsoever (i.e., graphology, punctuation, spelling, syntax and lexis).

${ }^{9}$ In this respect, it is worth referring to the current debate on language varieties, such as English as a lingua franca (also known as ELF) for interpersonal communication (cf. Phillipson 2003), and English as an international language for business and science communication (McKenzie 2007). Strikingly, a corpus analysis of the official document issued by The European Council, "The Common European Framework of Reference: Learning, Teaching, Assessment”, makes it possible to account for: the occurrence of the lexical items "native" (78 instances) / "foreign” (97 instances), such as in "foreign and second language", "foreign learners" or "foreign culture"; fewer occurrences of the item "international" (22 instances) and none concerning the phrase "lingua franca". 
and political significance of language teaching" (cf. "The Common European Framework of Reference: Learning, Teaching, Assessment”).

In so doing, many scholars advocate that teaching/learning foreign languages and their cultures (Byram 1988, Byram and Grundy 2003, Kramsch 1994, Melo et al. 2006, among other) ought to be interpreted not as "the other". Actually, further back in 1836, Humboldt stated (in Losonsky 1999: vii-xxxix), "to learn a new language is to acquire a new standpoint", even though it is a "new point of view still within the world-view of the old language" (that is, the mother tongue or L1, in contemporary terminology). At the macro-level, the foreign language learner/speaker "must migrate from one language system to another", posit Morgan and Cain (2000: 6), since mother tongue and foreign language operate "different discourse system[s] where lexical items often have different collocations or clusters of associated vocabulary". This view of language as a system is, thus, closely related to (Byram 1988: 41) identity, cultural heritage and values:

Thus language pre-eminently embodies the values and meanings of a culture, refers to cultural artefacts and signals people's cultural identity. Because of its symbolic and transparent nature language can stand alone and represent the rest of a culture's phenomena - most successfully in the literary use of language - and yet it points beyond itself and thereby constantly undermines its own independence.

When students' response is conveyed in the written form, students expand their independent writing skills while resorting to strategic, discursive, literary and cultural knowledge (Alarcão and Tavares 1986) to explore, compare and interpret hidden meanings. In the process, they gradually grasp appropriate conventions in the English language, from syntax and collocational meaning (while contrasting to its rendering in the mother tongue), to usage and mechanics. In this line, Harmer confers (1994: 182) an initial role to the lecturer's expertise in reactivating receptive skills, "which learners have in their own language but which may be less effective when they are faced with" the foreign language, so that "students feel less anxious and thus remove some of the barriers that alone may dramatically improve their receptive abilities".

It is also implied that texts and genres, following Halliday and Hasan (1985, 1989) and Martin (1996), are inevitably envisaged in their cultural dimensions (Bourdieu 1991), with a focus on: race, nationality, religion, social class, gender and political system. Hence, perceiving language use in a continuum of discourses encompasses FL learners' needs to cope with multiple literacies and language varieties of the same linguistic code, for example within the English speaking world. In this line, moves towards inter- and cross-disciplinarity have been suggested because English studies should be, so is the view shared by Weiss (1999: 54), "reshaped not only by the literary and cultural developments but also by English as international language-code of business and technological advancement".

There will never be a coinciding juxtaposition of languages or cultures within English-speaking countries. English is spoken with other influences. 
Consequently, issues relating to correctness are to be taken into account within a cross-disciplinary theoretical frame, because the context and domain, for example, shall define the adequacy and appropriacy of register. In fact, Swann (1996: 310) convincingly argues that "style", meaning speaking style, "is likely to operate in more than one dimension, allowing speakers access to a more complex range of social meanings", not randomly attributed. On the contrary, she concludes, "[one] need[s] a certain amount of contextual knowledge to interpret the use of different linguistic features", ranging from gender, age, race, cultural background of speakers (addresser/addressee), the setting, the format of interaction to the topic being discussed, to name but a few.

An urgent literacy and critical empowerment have changed the educational scenario and Portugal was thrown in the same endeavour from the last decade onwards with the onset of curricular reforms in education. These, too, have emphasised culture awareness presupposing the knowledge and acceptance of national and transnational, socio-cultural and linguistic dimensions without overlooking diverse past and present specificities. Along these tenets, subjects are supposed to become better equipped with critical and reflective tools to face the forthcoming ever-increasing demands in the inevitable globalising venture overwhelmed by a wider and wider gamut of information technological tools.

Two recurrent issues come to the fore, since (Bourne 1996: 243) "learners' attitudes towards English may be ambivalent”. First, "a positive national policy towards teaching a language”, especially at secondary school, "does not necessarily mean", posits Bourne, "that an individual is equally positive about learning that language" ${ }^{\prime 10}$. Second, the way English has been presented to learners/readers has had a strong impact on subjects' perception of the language, its use and usage, varieties and culture. Thirdly, English has become not only a lingua franca, claims Kayman ${ }^{11}$ (2000: 21), in the "name of the requirements of modern employment", but also the lingua economica, advances Phillipson (1996, 2002), because of

${ }^{10}$ The multifaceted EFL teaching/learning paradigm, as perceived by Byram and Grundy (2003: 1), "has developed in many directions and with considerable vigour in the last 10 to 15 years". It is marked by shifts from functional to communicative approaches, and "the origins lie partly within theory and practice of language teaching, and partly in response to the recognition of the social and political significance of language teaching”. Modern foreign languages in the English national curriculum in Portugal, quoting APPI Newsletter (2/2000: 9-10), "sets out two sorts of requirements: knowledge, skills and understanding - what has to be taught in MFL during the key stage (readers' foreign languages), and breadth of study" (abridged from The National Curriculum in England "Programme of Study: Modern Foreign Languages", Department for Education and Employment). In this line, English has been offered a key role in university curricula so as to foster students' linguistic and cultural diversity, to meet their practical needs and interact as engaged citizens "within the newly emergent social political structures" both in a European and global dimension, not to mention the need for "both diversity and ease of communication through the widespread use of English" in wideranging discourse communities.

${ }^{11}$ M. Kayman, a former full professor of English studies at Coimbra, has provided a more comprehensive account of the study of English, from its historical background up to curriculum design, as well as reforms of Portuguese university degrees in English majors for two centuries, in his paper entitled “A Very Old Alliance? An Introduction to English in Portugal”, edited by Engler and Haas (2000: 13-32). 
becoming more specific-oriented and privileging, for instance, the expository text for communicative purposes.

Along these lines, some believe that language teaching has reduced the notion of language to its so-called (Kayman 2000: 23) "pragmatic communicative functions", deprived of the "critical, linguistic and cultural capacities", in Kayman's view, presumably fostered (Op. cit., Ibidem) "in other component disciplines”, meeting, nonetheless, students' compliance considering their preoccupation (Op. cit., Ibidem) "with what they imagine to be their futures". The scholar's contention might find some grounding in Engler's argument (2000: 6) provided that "three persistent conflicts may be perceived, between autonomy and public service, between mother tongue and foreign language, and between European and global cultural integration".

"The foremost challenge facing English studies today", adds Weiss (1999: 54), "is the reconception of its identity within the university in such a way that it not only responds to economic globalization and technological change but also provides a new vision of the importance of interpretive, language and communication skills in the $21^{\mathrm{st}}$ century". Yet, advance Morgan and Cain (2000: 22-23), "the danger for the foreign language teacher may be that one set of cultural values is taken as universal". This seemed to be taught, to borrow from Kramsch's problem-posing (1994: 9), "via an educational culture which is itself the product of native conceptions and values". It constitutes, in her bearings, a "third culture"/"place".

Having briefly referred to the object, aim, relevance of the subject matter and research paradigm (exploratory analysis and corpus linguistics approach), setting and broad theoretical considerations, it is now the moment to turn to the presentation, discussion and illustration of the major tenets related to the problem which has triggered this paper.

\section{Language, Context and Culture}

A reading/writing knowledge of foreign languages is becoming more and more important at university level. Similarly, the emphasis goes beyond the former tenets on its spoken version so that secondary school leavers and FL learners in other fields of study may acquire the basic skills to communicate with other speakers in/of, for instance English, as the international language for communication. Accordingly, creativity has developed into a matter of guiding principle, even prerequisite, more than certification itself.

A close analysis of the most frequent collocates related to the lexemes "language" points to respondents' concern for lexical and syntactic competence as well as fluency in English, like: "improvement”, "development”, "vocabulary", "form" and "structure", as evidenced in the lines underneath.

Node - Language (some collocates)

[Secondary School Respondents' output (language - 22 instances)]

Left collocates 
10. y are more simplified and the contributed to language development. Eurico, O Presbítero 7H 112 Is

11. ored because it only helps us to improve our language, and it's something that takes up a lot of ou

12. 9106 8I 155 It's a way of improving our language and also a way of describing the other cultur

13. ties_ 9K 180 texts written in colloquial language $\quad 9 \mathrm{~K} 181$ lyrics $\quad 9 \mathrm{~K} 182 \quad 9 \mathrm{~K}$ 183 play

14. her like to reed in portuguese than in other Language. 9K 186 texts dealing with sports I think

15. 7654382 6F 86 I would describe it as language improvement. x x x x 182354 679

16. ifficult to ready in English, because of the language. 5E 63 historical texts (...) because it's

17. , its good for a better understanding of the language. x x $\quad$ x x $792316451089 \mathrm{~K}$ 180 It' $^{\prime}$

18. se is more comfortable to read in our proper language. $8 \mathrm{~J} 174$ historical, political, and literary

19. e learn and understand much more the foreign language. $\times 1 \times x \times 6785124937 \mathrm{H}$ $113 \mathrm{x}$

[Undergraduate Respondents’ Output (language - 17 instances)]

Left collocates

1. literary texts in Portuguese and other languages 8J 165 historical texts; novels; poems

1. d way of enlarging one's knowledge of a language. 10L 204 10L 205 A text with comple

2. to see how *conected students are with a language. 10L 211 10L 212 The student should

3. y which improves our ability to speak a language. 10L 215 Sometimes when the text is no

4. rde to understand/solve a problem about lanquage and structure. 10N 247 When I read a

5. es) To understand/solve a problem about language and structure. 10N 246 Cesário Verde t

6. ..) because they have a more *accesseble lanquage for us, students. Reading could be defin

7. to improve my acknowledge of English Lanquage. $\quad$ ó) $\mathrm{h}^{3} \tilde{\mathrm{N}} \neg^{3} \tilde{\mathrm{N}}{ }^{` o}-{ }^{-} \tilde{\mathrm{N}}$

8. ecause we learn more about the English lanquage. _Reading is to understand the words.

9. e real world through a specific kind of language, which is sometimes difficult to decodif

10. is an activity where we can check our language fluency and our observation and also our 11. tant for our literary awareness and our language improvement. $10 \mathrm{M} 235 \quad 10 \mathrm{M} 236 \mathrm{I}$ woul

12. y healthier but also more useful to our language skills. 10L 215 Because for many peopl 13. Because they have an easy and proper language for us, students._Reading_. 10L $217 \mathrm{~m}$

Unlike most informants' perception of reading in English to improve language accessibility and readability, Kintsch and Miller (1984: 220-221) contend that "readability is not a fixed property of text, but rather the result of the interaction between the reader and a text". The English language class frequently turns out to be an attempt to overcome some of the students' difficulties along with a worthy input of vocabulary, better saying a continuous struggle to improve their language production. In informants' output, most collates in the close environment of the adjectives "difficult" and "easy" (accessible) are represented in Table 2 (in the Appendix). 
It follows, then, to tag along Iser's line of reasoning ([1978]1994), that text readability, one of the factors in readers' main bias in text comprehension, should be equated in terms of accessibility. The latter, in turn, and to quote McRae (1991: 45), "depends more on how" the interaction of the learner/reader with the (spoken or written) text "than on any of the multiplicity of linguistic and cultural factors which may render it inaccessible". In other words, readability seems not to be exclusively tied up with unfamiliar or difficult lexical and/or syntactical choice, not to mention McRae's assertion on (Op. cit., Ibidem) “the culture gap”, but, strongly believe Carter and McRae (1996), with making them accessible by focusing on ways in to texts, whatever their type.

These may be possibly determined via close analysis of units of language and functions of language (the latter advanced by Jakobson 1971), given "the complexity of the communication process" (cited in Waugh et al. 1998: 15). Thus, langue and parole (Saussure 1959) should be conceived, in Jakobson's tenets on the speech event, as "code" and "message", thereby leading to the binaries speaker and addressee, "encoder" and "decoder", production and comprehension, "encoding” and "decoding”. Therefore, map out Waugh et al. (1998: 15), "the reality of linguistic phenomena, as well as the point of view of language users (speakers and addressees)", are preferred to the one "of the observer who is outside of the system and thus least able to understand its reality". Extending this perspective into "what Halliday calls the texture of texts", Candlin ${ }^{12}$ (1994: viii) reassesses the variability of text interpretation within the context of teaching and learning more than within language itself because of (Op. cit., Ibidem) "combining in the teacher and the learner... the roles of analyst and interpreter, integrating classification with making the meaningful intelligible”.

Hence, McCarthy and Carter further contend that (1994: 168) "learners are likely to gain more interest and to be more empowered as educated citizens if they also develop a critical capacity to see through language to the ideologies and values which particular stylistic choices encode". The understanding of these stylistic choices brings in (Clark 1996: 2) the analysis of language structures and patterns together with "the meaning of words within a textual framework". Moreover, and in the case of "representational texts", to follow McRae's claims on the study/learning of language as a literary medium (1991: 95), "these invite the reader to move on fairly rapidly to high order questions, probing the interpretive possibilities of the text, and beginning to look at the author's presumed intention, at the connotations and implications of what is written, at the wider subject matter the text touches upon" [scholar's emphasis].

Different methodologies are required to teaching English either as a second language ${ }^{13}$ (Labov 1972, Ellis 1985, Cook 1993) or a foreign one (cf. Grellet 1981,

${ }^{12}$ In his preface to Language as Discourse: Perspectives for Language Teaching by McCarthy and Carter (1994: viii-x).

${ }^{13}$ Cook, Ellis and Labov have extensively written about language and style, notably (Cook, Ibidem, p. 83) "variation in L2 according to speakers' social class and the task they were performing” on various levels: phonological, grammatical, pragmatic (mother tongue interference, codeswitching 
Nuttall 1982, Carrell et. al. 1993, Davies 1995 and Sinclair 1996) above all in what concerns transferring skills from individuals' mother tongue into the teaching and learning of a foreign language so as to avoid most FL speakers' anxiety for lacking lexical competence. In the process, a common (Engler, 2000: 6) "pursuit of knowledge" comes to the fore at the expense of "the development of a critical stance". Conversely, concludes Engler (Ibidem, 7), "those doing English in an English-speaking country find themselves, along with their colleagues in History and Sociology, at the centre of cultural debate, on the site where cultural meanings are formulated, enforced and displaced".

As for the lexical item "English” (39 instances/12 $2^{\text {th }}$ formers' corpus; 12 instances/undergraduates' corpus), a gamut of discursive practices and subjectmatters might be perceived (for instance, "textbook", "grammars", "books", "historical texts”, “comics”, "history” and "culture”). Indeed, to tag along Engler's view (Op. cit., Ibidem), most participants in the Portuguese educational community perceive English as a second language following the basic and secondary school national curricula terminology (Sequeira 1993: 8) whereas, advances Bourne (1996: 243), English was envisaged as "an additional language", limited to the formal setting of education, in the language classroom.

As a result, many EFL learners, posits Brumfit (in Mercer and Swann 1996: 273), "have loyalty to their mother tongue... self-realization may be a role for some individuals, but the prime purpose of learning English is to participate in an international community, expressing what it is to be Finnish, or Chinese, or Zairian in an international context”. Nevertheless, EFL learners' personal acquaintance with everyday English is fostered through their contact with (Engler 2000: 7) "popular culture (music and film)", not to mention the Internet as if they were in a second language environment, mainly through their use of words and concepts from English into their mother tongue. These are chiefly the scarce occasions of language/culture learning dimension, posits Engler (Op. cit., p. 7), "where innovation is strongest", especially because, adds the scholar, "elsewhere English will always be viewed against other languages". Furthermore, reports Brumfit (1996: 274), "until recently, the general consensus for mother-tongue learners was that the written language for education was the standard language of public print, adapted of course to specific communication purposes". In the course of changes of language policy in "the English National Curriculum (following the 1988 Education Act)", Brumfit goes on to explain (Op. cit., Ibidem), "there have been several attempts to introduce the notion of spoken standard English as a goal for all learners" or as is vindicated by one respondent (in the empirical research undertaken in Madeira):

13. ties_ $\quad 9 \mathrm{~K} 180$ texts written in colloquial language $\quad 9 \mathrm{~K} 181$ lyrics $\quad 9 \mathrm{~K} 182 \quad 9 \mathrm{~K} 183$ play

together with speakers' states of mind and knowledge of the language/s) and register shift, namely language variety, field, tenor and mode, as discussed by Halliday et al. (1985). 
On the contrary, another informant's reference to learning English with fun (for pleasure and language development), spelt out in the following string, contrasts with the kind of interaction most frequently stressing "otherness" implicit in very many respondents' reference to "historical texts" read in the EFL context for information purposes.

\section{7. comics it's a different form of learning English, with entertainment. No. $5 E 63$ the Eng}

As for the collocates to the item "Portuguese", albeit with fewer occurrences (16 instances $/ 12^{\text {th }}$ formers' corpus; 4 instances/undergraduates' corpus), they seem to account for respondents' aesthetic involvement with the mother tongue, as is required in national examinations. It is evidenced by the large amount of texts in all genres, including canonical and canon-breaking contemporary works ${ }^{14}$, or the socalled representative texts of a linguistic community. Interestingly, for the argument at stake, is the fact that enhancing reading and writing skills in students' mother tongue, either in spoken or written language, through Portuguese contemporary texts, has constituted one of the tenets of secondary school education in Portugal. Indeed, reading poetry is flashed out in this empirical research as a compulsory activity undertaken in the formal context of language learning, with a higher incidence on the mother tongue, taking into account the number of canonical poems by Portuguese writers indicated by respondents (thus reinforcing literary and culture awareness in their native language). Actually, four secondary school respondents stood out in the sample due to their readings of James Morrison's poems somehow, which are somehow tied up with adolescents' preferences for singers' lyrics (sometimes making part of textbooks' set of poems supplied).

\section{Node - Portuguese}

[Secondary school respondents' output] Left collocates

1. 7H 123 historical texts in English and Portuquese $7 \mathrm{H} 124$ all kinds of texts $7 \mathrm{H} 125$ tex

2. ; psychology texts; texts in German and $\underline{\text { Portuquese }}$ 8J 163 literary texts; newspapers; mag

3. a 8J 174 texts in English, German and Portuquese $8 \mathrm{~J} 175$ narrative texts; textbooks 9K

4. xts 7H 120 historical texts 7H 121 Portuguese novels (Fernado Pessoa; Virgílio Castelo

5. all kinds of texts 8I 133 historical Portuquese literature 8I 134 literary texts 8I

6. 66 5E 67 5E 68 Boring! Why not in Portuguese 5E 69 A waste of time! It is so Boring

7. H 111 historcal texts; poetry; texts in Portuguese and English 7H 112 historcal texts; te

8. 64 informative texts; literary texts in $\underline{\text { Portuguese }}$ and other languages $8 \mathrm{~J} 165$ historical

9. ledge. Because I rather like to reed in portuguese than in other Language. 9K 186 texts d

10. ulture-based texts I prefer reading in Portuguese, but I have already read for example Jan

11. lish 7H 112 historcal texts; texts in Portuguese, French and English 7H 113 informative

${ }^{14}$ Undergraduates' percentage of illustrations outperformed the ones by $12^{\text {th }}$ formers albeit both lists comprised, to a large extent, "best-selling novels", for instance, O Alquimista [The Alchemist] (amidst undergraduates), Como Água para Chocolate [Like Water for Chocolate], A História Interminável [The Neverending Story], and Sidharta (out of $12^{\text {th }}$ formers' references). In addition, there were texts with which they were most acquainted either in the formal setting of education or through media book reading promotions, mostly in Portuguese originals, for example Amor de Perdição [Doomed Love], As Viagens na Minha Terra, and a few in English, like Romeo and Juliet, The Bluest Eye or The Longest Memory, among others. Besides and most importantly, all these were available in local stores and / or bookshops. 
12. at can't buy it. 8I 133 Especially in Portuguese, they gave us books to read, that are no

13. Girl 8I 137 8I 138 I use them in Portuquese. 8I 139 8I 140 It's useful becaus

14. belongs to us. Because I study more in Portuquese. $5 \mathrm{E} 65$ _interesting_texts (...) becau

15. rarely read in English because I prefer portuquese, It is easiest to understand the story.

16. so until in 10th year I had a terrific Portuquese teacher who brought to class plenty of I

[Undergraduate respondents’ output]

Left collocates

1. Pedra; Memorial do Convento English and Portuguese grammars newspapers Cal; Viagens na Minh

2. ); Cal, MacLaverty; (and many others in Portuguese) 10L 211 romance novels Cal, Bernard M

3. om school rarely I find that. 10L 219 Portuguese authors A book is read in a more relaxed

4. ometimes is not for pleasure. 10N 245 Portuguese ones: Fernando Pessoa; Florbela Espanca;

Strikingly, the possessive determiner "our" and the indefinite determiner "other" occurred a couple of times in a closer context with the nodes language and English. As a consequence, these were object of scrutiny and they have come up to unearth the (Morgan and Cain 2000: 5) "the referential/denotative relation of language and culture" in the sense that "the denotative, referential aspect of language relies on an understanding of cultural norms".

\section{Nodes - Language; English}

Frequent Collocates: our; other

29 ther like to reed in portuguese than in other Language. 9K 186 texts dealing with spo

30 texts; literary texts in Portuguese and other languages 8J 165 historical texts; nove

10 ts 10M 241 magazines and newspapers in other languages; novels; texts from textbooks

1 o useful. 10L 214 texts about life in other countries (...) because it contributes $t$

. ored because it only helps us to improve our language, and it's something that takes up a lot of ou

. 9106 8I 155 It's a way of improving our language and also a way of describing the other cultur

. tant for our literary awareness and our language improvement. 10M 235 10M 236 I woul . y healthier but also more useful to our language skills. 10L 215 Because for many people

se is more comfortable to read in our proper language. $8 \mathrm{~J} 174$ historical, political, and literary

[“proper” in the sense of “own”/mother tongue - L1 interference]

s (...) because we improve not only our english but also our nowlege Reading is a way of

Actually, the lexeme "our" occurred more expressively in undergraduates' corpus (125 occurrences) than in $12^{\text {th }}$ formers' one (38 occurrences) around clusters associated with the cognitive dimension of reading, language skills, agency and the formal setting of instruction. Language development and knowledge about culture appeared likewise tied up with the reading activity, triggered mostly for information, rather than for personal growth, likely to be illustrated in the following strings:

Node - Our (some collocates) 


\section{[Secondary school respondents’ output]}

Right collocates

$11 \mathrm{nk}$ that reading is specially increasing our cultural level but any answer could be c

12 e. 6F 87 Reading is a way to enlarge our culture, our *horizonts, giving ous new e

13 the book and, as a consequence enlarge our culture. 9K 177 crime novels; lyrics Fi

49 elligent way of learning, and developed our mind and *aculturation. 6G 102 dialogue

419106 8I 155 It's a way of improving our language and also a way of describing th

42 red because it only helps us to improve our language, and it's something that takes

83 assical novels The best way to enlarge our vocabulary and it is also a way to enjoy

84 nificance in the topic A way to improve our vocabulary, but more important: reading

85 omething with them The act of enlarging our vocabulary, enjoying ourselves, learning

86 good way to expand our imagination and our vocabulary. 4D 30 texts about current

87 It's a way of learning and expanding our vocabulary. 6F 96 nothing It's pick up

[Undergraduate respondents’ output]

Right collocates

13 y opinion Reading can help us to extend our cultural knowledge. 10L 213 short-stori

14 about something and of contributing to our cultural knowledge. 10M 225 textbooks (

15 nk that reading is specially increasing our cultural level but any answer could be c

16 e. 6F 87 Reading is a way to enlarge our culture, our horizonts, giving ous new e

17 untries (...) because it contributes to our culture. 10L 215 stories; texts about

18 the book and, as a consequence enlarge our culture. 9K 177 crime novels; lyrics Fi

539106 8I 155 It’s a way of improving our language and also a way of describing th

54 ading is an activity where we can check our language fluency and our observation and

55 mportant for our literary awareness and our language improvement. 10M 235 10M 236

56 only healthier but also more useful to our language skills. 10L 215 Because for ma

57 red because it only helps us to improve our language, and it's something that takes

96 Because is more comfortable to read in our proper language. 8J 174 historical, pol

119 assical novels The best way to enlarge our vocabulary and it is also a way to enjoy

120 etween lines. 10N 252 It helps broaden our vocabulary but can sometimes be boring

121 nificance in the topic A way to improve our vocabulary, but more important: reading

122 omething with them The act of enlarging our vocabulary, enjoying ourselves, learning

123 good way to expand our imagination and our vocabulary. 4D 30 texts about current

124 hobby, or should be one, that enriches our vocabulary. 10N 253 excerpts of books s

125 It's a way of learning and expanding $\underline{\text { our }}$ vocabulary. 6F 96 nothing It's pick up

Thus, Morgan and Cain (2000: 5) refer to the impact of an overemphasis on the referential relation of language and culture, on the grounds of "the belief in literal meaning”, and quoting Rommetveit (1988: 14-15), “tacitly taken-for-granted background conditions" which can "lead to superficial and sometimes misleading understanding, where the cultural context of the country and the context of the individual are ignored”. In fact, reading materials overlooking both students' language and cultural background, not to mention less challenging subject-matters, sometimes perceived for their historical cline, may be inferred from informants' value judgements, particularly in the items directed to their "giving reasons" or further observations (in the reading evaluation questionnaire). 
However, undergraduates' claim for agency is likely to be disclosed in the number of instances related to the deictic expressions "our" (opinion/s, ideas, personal, own, selves, lives) and “other” (people’s opinion/s), especially:

"to learn about the country whose language one is learning”. (Inf. 203)

"contributes to our culture”. (Inf. 214)

It might be inferred that the possessive deictic "our", deemed liberating, involves a plurality of voices, and discursive selves sharing a linguistic community and culture which interact dialogically, thereby contributing to the formation of the individual's identity and agency. Furthermore, it connotes autonomous thinking beyond history, across disciplines in terms of the ethics of facing the real and the way it is frequently unveiled in the pedagogic setting. Interestingly, most of the inferences drawn from respondents' output, and presented so far, revolve around three main arguments concerning the triad language/literature/culture shared by Kramsch (1994: 11-12):

i) Its main goal can no longer be the one-sided response to national and economic interests, and the pursuit of communicative happiness; it must include the search for an understanding of cultural boundaries and an attempt to come to terms with these boundaries.

ii) The dichotomy between language as an expression of personal meaning and language as a reflection of the social order is already inscribed in the very way we write about "texts" on the one hand and "contexts" on the other. It reflects the fundamental polarity of linguistic discourse that describes language use as both the creation of texts and the shaping of contexts.

iii) Given that language teachers have to teach both a normative linguistic system and its variable instants of use, attention to context calls for a type of pedagogy that fosters both direct and indirect ways of transmitting knowledge, that values not only facts but relations between facts, that encourages diversity of experience and reflection on that diversity.

\section{Language and Cultural Awareness}

In the line of the standards defined for foreign language teaching ${ }^{15}$, the constellation of tenets underlying a foreign language syllabus (L. E. I syllabus) ${ }^{16}$, designed after the major Reform in education in Portugal, comprised three main dimensions, linguisticcommunicative and cultural agenda, forwarded by building on identity issues, "I - me my world" > "us - them - their world", to use Hartnack’s stance (1999: 149), and interaction across the curriculum, in that students "reinforce and further their

\footnotetext{
15 "Standards for Foreign Language Learning: Preparing for the $21^{\text {st }}$ Century" (Communication, Communities, Cultures, Comparisons, Connections) consulted on 21/10/1998, at url:http://www.cortland.edu/flteach.

${ }^{16}$ See, for example, DGEBS (1993), Novos Programas de Inglês do Ensino Básico e Secundário $3^{\mathrm{a}}$ Leitura, Lisbon: Editorial Ministério da Educação; Ministério da Educação - Sistema Educativo Actual e Expectativas Face à Reforma em Curso (1987), Lisbon: Editorial Ministério da Educação.
} 
knowledge of other disciplines through the foreign language”. Consequently, a process-oriented approach is fostered, which combines philosophical guiding principles, with a focus on learner autonomy, and a psychological cline, with its cognitive and socio-affective dimension in the process of teaching/learning.

EFL speakers'/students' task, suggests Harmer (1994: 185) within the pedagogical point of view, entails their interaction with the text in order to understand its meaning potential (Halliday 1989) "and this seems possible”, suggests Harmer (Op. cit., p. 185), "even where the text contains language which the students are not able to produce. All over the world there are students who can read English (often for scientific or academic purposes) but who are unable to speak it very well”.

In this respect, advance Sealey and Carter (2004: 143), developing intercultural and communicative competence involves procedural knowledge, subjects' awareness and interaction with speech communities and discursive practices. Nevertheless, posit Morgan and Cain (2000: 6), the "understanding of constructs lying beyond one's cultural boundaries is possible" if "alternative new lexical items and also frequently alternative conceptual categories" are learnt via a meaningful interaction with another language and culture.

However, FL speakers seemed to hold on to a reductive assumption of the foreign language as explained by Brown (1990: 145), in as much as "understanding seemed to imply being able to memorize the discourse and then being able to demonstrate that you had: (i) correctly identified the words used; (ii) correctly identified the meanings of the words; and (iii) correctly identified the cohesive structure of the discourse".

The following concordance lines offered some evidence to the previous argument despite the time span mediating Brown's comment critical stance and this empirical research. Accordingly, and to borrow from Sealey and Carter (2004: 153), "this view carries the implication that cultures are fixed, limited" and individuals are "bounded to the place they were born or the language they speak".

\section{Node - Meaning}

[Secondary school respondents' output]

Left collocates

1 horoughly to understand its content and meaning. 10M 229 Text decoding. 10M 230 While

2 e some questionaries to understand it's meaning. 2B 7 2B 8 2B 9 Good. 2B 10 As som

3 ly reading a text and understanding its meaning. 10L $210 \mathrm{~A}$ reading comprehension is som

4 (...) because all of them have a second meaning and purpose Reading is something that we

5 10M 224 We have to read for the second meaning. 10M 225 A reading comprehension activi

6 er help us when we don't understand the meaning of some subjects. Reding is a comprehens

7 thave the time or don't understand the meaning of that book. 1A 6 2B 7 I think the

8 are useful when we don't understand the meaning of the book and when we have doubts.

9 in school we learn how to compreend the meaning of the texts, this will help to the read

10 mes Because i like to understand the meaning of the whole text. 5E 82 frequently Fer 
11 , how they are structured, what are the meaning of the words (grammatically). 10N 249 I

12 Because its important to understand the meaning that we read all that is relative to the

13 4D 46 It is useful to understand the meaning, message of the book. 4D 47 By using t

14 vocabulary I did not understand and the meaning. 10N 249 I just read for compulsory

rea

15 o describe the name itself explains the meaning. In my opinion is a better way for us to

16 the textbooks. 10M 227 Understand the meaning/meanings the text can have. 10M 228 Rea

[Undergraduate respondents’ output]

Left collocates

1 thoroughly to understand its content and meaning. 10M 229 Text decoding. 10M 230 While we ar

2 inly reading a text and understanding its meaning. 10L $210 \mathrm{~A}$ reading comprehension is somethin

3 s (...) because all of them have a second meaning and purpose Reading is something that we must

4 10M 224 We have to read for the second meaning. 10M 225 A reading comprehension activity is

5 es, how they are structured, what are the meaning of the words (grammatically). 10N 249 It is

6 e vocabulary I did not understand and the meaning. 10N 249 I just read for compulsory reasons.

7 of the textbooks. 10M 227 Understand the meaning/meanings the text can have. $10 \mathrm{M}$ 228 Read a

Additionally, Leech's (1990) linguistics perspective on the study of meaning plays a crucial role in interpreting messages at different levels for its stress on the communication system itself. Seven types of meaning come forth in his (Op. cit., p. 20) "accounting for all that a piece of language may communicate", of which boundaries are sometimes difficult to "demarcate" and "more especially, problems of separating conceptual meaning from the more peripheral categories" come to the fore. Hierarchically displayed in Leech's Semantics (1990), "meaning" or "communicative value", the scholar's alternative term (Op. cit., 23) "embracing the wider sense", comprises three major groups pointing to conceptual meaning, associative meaning and thematic meaning with relation to what is communicated. They are defined as follows (Op. cit., Ibidem): i) conceptual meaning or sense [author's emphasis] - "logical, cognitive, or denotative meaning"; ii) connotative meaning - "by virtue of what language refers to"; iii) social meaning - "of the social circumstances of language use"; iv) affective meaning - "of the feelings and attitudes of the speaker/writer"; v) reflective meaning - "through association with another sense of the same expression"; vi) collocative meaning - "through association with words which tend to occur in the environment of another word"; vii) thematic meaning - "by the way in which the message is organized in terms of order and emphasis”.

Moreover, subjects' concern for "background” knowledge, and catching up with the world around to cope with current demands (for example, immediate assessment purposes, professional and personal interests in the ever-increasing cognitive shifts in society), stood out in their response illustrated by the often 
occurring lexemes within the same lexico-semantic field: "know" (101) and "knowledge" (45). Besides, some of the present-day trendy television contests offer but one instance of "general culture" (Inf. 160) while checking on competitors' knowledge of, i.e., "cultural issues, international affairs, psychology, science and technology, art, literature, history, mother tongue's grammar". These have standardised adolescents' cultural consumption broadly headed under categories like, to quote their recurrent remarks, "informative texts", "descriptive texts", "cultural texts", to be unveiled in the following strings selected from the corpus on the lexico-semantic field, background knowledge, for illustrative purposes:

\section{Lexico-Semantic Field: Background Knowledge \\ Lexeme: Knowledge (some collocates)}

[Secondary school respondents' output (knowledge - 29 instances)]

8 exts in manuals which give general knowledge of things I just read texts in ma 15 he reading. A way of improving our knowledge $5 \mathrm{E} 48$ I like reading that becau 16 in class because we can expand our knowledge about certain matters. 5E 59 ma 17 elp us. 5E $62 *$ Usefull to see our knowledge and comprehension of the texts. 18 e mind (eyes) absorbs enriches our knowledge and culture. It is a very pleasant the $29 \mathrm{~K} ; 193$ It is when you enrich your knowledge and expand your learning capacity

[Undergraduate respondents’ output (knowledge - 16 instances)]

Left collocates

1 It is a pleasant way of acquiring knowledge and widening your imagination. 1

3 all demand concentration, capital knowledge of the language skills, interest $\mathrm{f}$

4 nd of contributing to our cultural knowledge. 10M;225 textbooks (...) as thei

\section{Lexeme: Know}

[Secondary school respondents' output (know - 82 instances)]

Right collocates

20 of the book 8I 156 8J 157 I like to know different* opinions, so I can suit the bes rical and culture-based texts I like to know different cultures and or historys*. 5E historical texts (...) because it good to know histories from the passed and helps us $\mathrm{t}$ 45108 5E 68 the help of our teacher, To know/learn the more difficult words. $\mathrm{x} \mathrm{x}$ 46 formative texts (...) because we get to know, lots of things about many topics. $7 \mathrm{H}$ 47 ure-based texts (...) because I like to know more about different places around the $\mathrm{w}$ 58 6G 101 6G 102 Because it's good to know some good or bad critics, to make us und 59 ext 9K 193 Because it's always good to know someone else's opinion. 9K 194 Because

[Undergraduate respondents' output]

Right collocates

1 o-day events (...) because it's good to know about what is happening around us. $10 \mathrm{M}$ on may not be sufficient and we have to know another people's view about the reading. teinbeck 10L 205 books from authors I know magazines; newspapers some types of maga

8211 Everytime we read a book we get to know new things, in the second time we see ot

9 s r f s because it is very important to know others* opinion 10L 211 s r s s Sometime

10 10L 210 because it is very important to know others* opinion 10L 211 Sometimes we

11 ovels; poems (...) because if we do not know something we can ask the teacher. Readin

12 have a general idea of the novel and to know the author. 10L 205 10L 206 10L

13 the most important facts that we should know. The Bluest Eye, Toni Morrison 10M 233 
14 don’t remember 10L 219 They help us to know the main ideas before an exam Não Há Lon

15 more relaxed way because I only have to know the most important things, not to have a 10L $212 \mathrm{~s}$ r s s Because I would like to know the point of view of another person to s

19 s and activity you do to check what you know, your own interpretation of the text. 1

Background knowledge, a component in the interpreting process, either of topic or cultural nature, has been assigned a relevant role in L1 and L2 (Coady 1979, Bernhardt 1991). Following Urquhart and Weir's broad label on "content-oriented readings", these might cover the purpose underlying subjects' frequent allusion to phrases possibly associated with "background knowledge", "cultural knowledge", "knowledge of the world", "general knowledge" (a label spread in the media apparently familiar to respondents), all of which seemingly driven by an informative reading goal.

In Kramsch's stance (1994: 23-24, Tajfel 1982) the aforementioned situation owes extensively to the teaching of culture in the language setting, apparently stemming from two main directions and perceived separately in the FL context:

It has focused on cultural information: statistical information (institutional structures and facts of civilization), highbrow information (the classics of literature and the arts) and lowbrow information (the foods, fairs, and folklore of everyday life). This view of culture has favored facts over meanings and has not enabled learners to understand foreign attitudes, values, and mindsets. It has kept learners unaware of the multiple facets of the target group's cultural identity. It has left them blind to their own social and cultural identity, implicitly assuming a consensus between their world and the other.

The schematic display of the node text, and collocates, in Table 1, together with the encoding of categories of open items in the questionnaires, is meant to offer a comprehensive view of the sort of materials/texts as they seem to be perceived by respondents. The lexical items have been sorted out by parts of speech and associated meanings.

In both encodings two aspects, implicit in text definition in accordance with text's purpose, may be inferred: on the one level, the transactional meaning (Halliday 1993), mostly in the instances associated with ii. (as follows), due to the gamut of items on transactional language (i.e., "language used to obtain goods and services", Nunan 1993: 20); on the other level, interpersonal language (i.e., "language used for socialising”, Op. cit., Ibidem):

$i$. right collocates underpinning texts' themes - the node followed by present or past participle forms of the verbs "link" and "relate" or even several prepositions not only pointing to texts' source, origin, display and aim, not to mention "undefined kind", in the case of the node being followed by an adjective (i.e., rich), or a defining relative clause;

ii. left collocates, mostly adjectives in premodifying position, associating texts with discursive practices and discourse communities (Mercer and Maidment 1996) 
conveyed by the dissimilar subject-matters explicitly stated in the scope of culture, history, philosophy, sports, science, technology and geography.

TABLE 1. TEXT: Normalisation of Lexico-Semantic Collocates by Corpora/Institution

\begin{tabular}{|c|c|c|c|c|}
\hline Node & Collocates & $\begin{array}{l}\text { Secondary } \\
\text { School }\end{array}$ & University & Total \\
\hline \multirow{2}{*}{ text $+\mathbf{V}$-ing } & dealing & 12 & 5 & 17 \\
\hline & depending & 1 & & 1 \\
\hline \multirow{3}{*}{ text $+\mathbf{V}$-ed } & linked & 2 & & 2 \\
\hline & related (for comprehension) & 12 & 2 & 14 \\
\hline & $\begin{array}{l}\text { based (on current affairs / personal } \\
\text { experience/ personal opinions/society themes) }\end{array}$ & 13 & 2 & 15 \\
\hline \multirow{6}{*}{ text + PREP. } & about & 29 & 2 & 31 \\
\hline & on & 11 & & 11 \\
\hline & from & 16 & 2 & 18 \\
\hline & in & 12 & 1 & 13 \\
\hline & for & 4 & & 4 \\
\hline & with & 1 & & 1 \\
\hline \multirow{2}{*}{$\begin{array}{c}\text { text }+ \\
\text { CLAUSE }\end{array}$} & which & 22 & 4 & 26 \\
\hline & that & 13 & 2 & 15 \\
\hline text + ADJ & rich & 1 & & 1 \\
\hline \multicolumn{2}{|r|}{ Total (a) } & $149(26.3 \%)$ & $20(21.7 \%)$ & $169(25.6 \%)$ \\
\hline \multirow{18}{*}{$\mathbf{A D J}+t e x t$} & subject/topics & 3 & & 3 \\
\hline & culture-based & 32 & 3 & 35 \\
\hline & culture-related & 2 & & 2 \\
\hline & culture & 32 & & 32 \\
\hline & cultural & 2 & & 2 \\
\hline & historical texts & 73 & 4 & 77 \\
\hline & history & 2 & & 2 \\
\hline & philosophical & 2 & & 2 \\
\hline & sports-related texts & 2 & & 2 \\
\hline & sports & 2 & & 2 \\
\hline & music & 1 & & 1 \\
\hline & scientific/technical & 14 & 10 & 24 \\
\hline & technology & 1 & & 1 \\
\hline & geographical/planets & 2 & & 2 \\
\hline & psychology & 2 & & 2 \\
\hline & factual/facts & 2 & & 2 \\
\hline & current/contemporary/affairs & 5 & & 5 \\
\hline & society & 1 & & 1 \\
\hline \multicolumn{2}{|r|}{ Total (b) } & $180(31.7 \%)$ & $17(18.5 \%)$ & $197(29.9 \%)$ \\
\hline
\end{tabular}

Note: Counts in the two texts normed to a basis per 100 words of text bearing in mind the node [ $\mathrm{N}=567$ instances/Sec. School (17.5\%o); 92 instances/University (8.1\%o)].

Bearing in mind the context of occurrence of the collocates to the node Text, there was a striking rise in the percentage of attributives on discursive practices/communities and subject-matters, predominantly underpinning $12^{\text {th }}$ 
formers' perceptions of text(s). Yet, undergraduates' output might be perceived to occur along a wider semantic scope: "culture-based"/"related"; "historical texts" and "scientific"/"technical", in a larger number of observations presumably connected to the diverse panoply of texts with which they interact for academic purposes. Furthermore, and consistently reiterated, appear the number of instances falling upon the binary "literary text" (ideational function) inasmuch as "informative texts" (transactional and interpersonal functions) in undergraduates' corpus purportedly supporting their developing view of text types and purposes. In addition, informants' affective identification with a foreign language/culture reinforced by the so-called "cultural artefacts" (Byram 1988: 41) has turned out to fall upon the category of "popular culture".

Respondents' frequent allusion to "dialogues" as favourite texts in the EFL setting were perceived to contrast with the sort of spoken exchanges occurring in many formal settings which entail (Morgan and Caine 2000: 21) "a fixed format", that is, "statement A is followed by response B". Hence, "dialogues", bearing in mind the context of occurrence of the node, appeared not to be related to a kind "of conversational interaction or discourse, earnest rather than chatty", to follow Wales's (1997: 122) definition, but to the dialogic form of "shared event" put forth by Bakhtin ([1935] 1990). These may be found both in written genres, like "novel" and "drama", as well as in spoken genres, that is, "interviews, conversation, and lesson", to follow Kress (1997) and his "contrastive analysis of three spoken genres”, also mentioned by Talbot (1995: 44).

\section{Node - Dialogue}

[Secondary School Informants' Written Output]

Right collocates

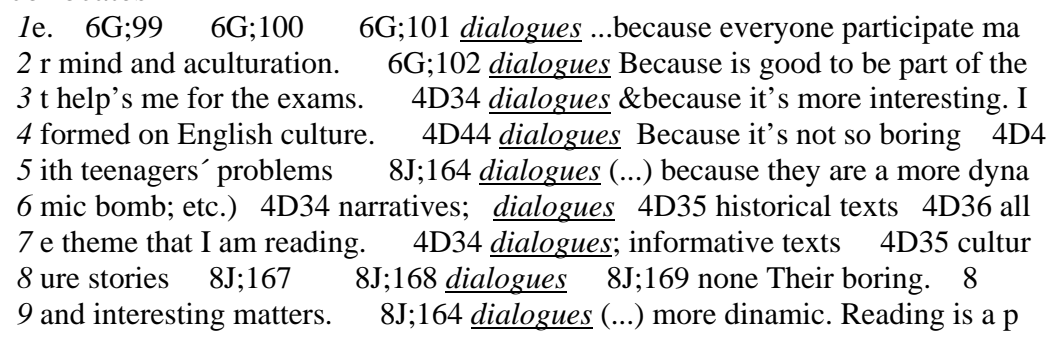

Conversely, "dialogues", either as types of text read in manuals (Inf. 35), or favourite text types for their dialogic stance, were illustrated as a collocate of the lexical item "dialogue" within the context of "interesting" and "boring". These are likely to be understood along Kramsch's claims on (1994: 30) "the profound pleasure that comes from understanding and being understood, from discovering multiple layers of meaning and having the ability and power to manipulate these meanings". Moreover, the co-occurrence of words/phrases like "participate" and "be part", have unearthed the semantic density of the node because, explains Kramsch (Op. cit., p. 28), 
by identifying and discussing the dialogic context itself, the participants in the dialogue are given validity and importance as speakers and hearers in that dialogue; their contributions are given breadth and depth. By attending both to their own agenda and to that of their interlocutors, language learners can start using the foreign language not merely as imperfect native speakers, but as speakers in their own right.

Actually, the literature review on reading and its implication for teaching, especially on the construction of shared events and discursive selves (Devine 1993, Carrell 1993, 1998 and Eskey 1993), strongly recommended “dialogues”, amidst tapes/tapescripts and (Devine 1993: 268) "even carefully screened reading materials", in the pedagogic context, for offering (Op. cit., Ibidem) "a rich linguistic environment in which readers will be exposed to topically interesting and situationally appropriate language samples". These are easily followed even by (Op. cit., Ibidem) "low-language proficiency readers". Most importantly, posits Kramsch (1994: 13), "The educational challenge is teaching language "as context" within a dialogic pedagogy that makes context explicit, thus enabling text and context to interact dialectically" (author's emphasis).

\section{Conclusion}

From the data presented and succinctly discussed so far it might be inferred that two sorts of approaches underpin EFL teaching learning: one, a cultural approach associated with cultural literacy and communicative competence and the other, an intercultural approach (Byram 1998: 51), more in the line of (Morgan and Cain 2000: 8) "an interactive dialectical process". In addition, informants' response to reading involvement in the EFL setting evidenced ambivalent attitudes:

i. the unduly stress on interacting with the target culture for extrinsic values, rather than promoting cultural and linguistic diversity, according to which speakers' mother tongue and foreign language and cultures should interact (not holding universal traits in the Foucauldian stance); likely to be illustrated with the stance:

"improving our language and also a way of describing the other cultures" (Inf. 155)

ii. Or the opposite, that is "inferiority of the recipient countr[y]" might be inferred, to use Pennycook's remark (cited in Dendrinos 1996: 260) and refer to Kramsch's tenet on "the third culture", possibly evidenced in:

or text which we study are boring, now English is like history. 7H 122 sometimes Fern

It is, thus, unveiled that the dialogic interaction of mother tongue and foreign language can be enhanced (Bakhtin [1935] 1990, Rex 2001: 292) "through classroom dialogue that locally constructs new positionings." Hence, "it is in this development of the foreign language learner as both a social and an individual 
speaker”, contends Kramsch (1994: 28), "that we have to see the emergence of culture in the language classroom". Therefore, the binary same/other in the dialogic encounter of mother tongue and foreign language ends up creating a "special space and time at the boundaries between two views of the world". When, for instance, Belsey (2002) argues that language learning implies the acquisition of a set of (Op. cit., p. 41) "differentiating concepts which identify not given entities but socially constructed meanings" [author's emphasis], the so-called linguistic determinism, she does not exclude the productive essence of language to which subjects resort so as to challenge ideology and common sense along with constructing ([1980] 2002: 43) "new meanings and new ways of analyzing the world”. As Belsey briefly points out (Op. cit., Ibidem):

$i$. This view of constantly evolving discursive contexts and genres resists efforts to depict content as fixed, learning as acquisitive, and interactional practices as structural constancy.

ii. This view forwards reading curriculum as dialogic activities rich with member discussions of value, purpose, and goals, which construct local models rather than received models.

In addition, a "dialogic encounter of cultures”, so read Bakhtin's postulates (1990: 7), should be referred for its pertinence provided that cultures should "not result in merging or mixing", because "each retains its own unity and open totality, but they are mutually enriched" [author's emphasis]. Therefore, overlapping languages and cultures should not be leading to a common ground, and differences should be seen in context, rather than overlooked, so that individual values whatever their nature should be preserved. Besides, as was reminded by Humboldt ([1836] 1999: 21), a foreign language learning setting ought to encompass the meaning "foreign but not strange" (for the common Greek etymology giving rise to two lexical items in romance languages, "estrangeiro" and "estranho", clearly disentangled meanings in Portuguese) since "it promotes in its turn the correct evaluation of the individual".

Similarly, from a postmodern perspective, as advanced by Usher and Edwards (1994: 16), "the centred subject does not exist naturally and pre-formed but is rather a cultural construct, inscribed in the meaning system, that is language, and by discourses, particular and systematic uses of language" [authors' emphases]. Above and beyond, both teachers' and students' search for truth not only transcends the educational setting and their involvement with the outside reality, including undervalued communities, but also constitutes a new site for effective learning, by going beyond the limited boundaries of home (family life) and language classrooms/lecture settings.

There will be a permanent linguistic and cultural enrichment between mother tongue and foreign language interaction. Language choice and purpose ought to be perceived in a continuum of discourses and by no means dissociated from the "cultural construction in which our very selves and sense are constituted", so are Chambers' claims borrowing from Kirby (1995: 22). 
All in all, and to draw on Chambers (1994: 24), as well: "Our sense of being, of identity and language, is experienced and extrapolated from movement: the "I" does not pre-exist this movement and then go out into the world, the "I" is constantly being formed and reformed in such movement in the world".

\section{Appendix}

TABLE 2. "Easy" / "Difficult" : Collocates per Informants' Corpora

\begin{tabular}{|c|c|c|c|c|}
\hline \multirow{2}{*}{ Corpora } & \multicolumn{2}{|c|}{ easy } & \multicolumn{2}{|c|}{ difficult } \\
\hline & Noun & Verb (to Infinitive) & Noun & $\begin{array}{c}\text { Verb (to } \\
\text { Infinitive) }\end{array}$ \\
\hline \multirow[b]{2}{*}{$\begin{array}{l}\text { 12th } \\
\text { Formers' } \\
\text { Output }\end{array}$} & \multicolumn{2}{|c|}{ Collocates for [Easy] = 15} & \multicolumn{2}{|c|}{ Collocates for [Difficult] $=20$} \\
\hline & $\begin{array}{ll}- & \text { language } \\
\text { - } & \text { texts } \\
\text { - } & \text { textbooks } \\
\text { - } & \text { vocabulary }\end{array}$ & $\begin{array}{ll}\text { - } & \text { to read } \\
\text { - } & \text { to understand } \\
\text { - } & \text { to interpret } \\
\text { - } & \text { to study } \\
\text { - } & \text { to answer }\end{array}$ & $\begin{array}{ll}- & \text { language } \\
\text { - } & \text { words } \\
\text { - } & \text { texts } \\
\text { - } & \text { book }\end{array}$ & $\begin{array}{l}\text { - } \text { to read in } \\
\text { English } \\
\text { - } \text { to read books }\end{array}$ \\
\hline \multirow{2}{*}{$\begin{array}{l}\text { UMa } \\
\text { Undergraduates, } \\
\text { Output }\end{array}$} & \multicolumn{2}{|c|}{ Collocates for [Easy] $=6$} & \multicolumn{2}{|c|}{ Collocates for [Difficult] $=10$} \\
\hline & $\begin{array}{ll}- & \text { language } \\
- & \text { reading } \\
- & \text { ways of } \\
\text { knowing } \\
\text { things }\end{array}$ & $\begin{array}{ll}- & \text { to understand } \\
\text { - } & \text { to work } \\
\text { - } & \text { to work and } \\
& \text { understand } \\
\text { [short stories] }\end{array}$ & $\begin{array}{ll}\text { - } & \text { language } \\
\text { - } & \text { texts } \\
& \text { parts of } \\
\text { - } & \text { the text } \\
\text { - } & \text { books } \\
& \text { books } \\
& \text { [classical } \\
& \text { novels] }\end{array}$ & $\begin{array}{l}\text { - to understand } \\
\text { [novel / parts of } \\
\text { speech] } \\
\text { - to decode }\end{array}$ \\
\hline
\end{tabular}

\section{Editors' note:}

This article is the author's contribution to the Proceedings of the Exploratory Workshop Linguistic and Intercultural Education in the Process of Europeanisation of Higher Education CLIE-2009, Popescu, T \& Pioariu R (Eds.). Aeternitas: AlbaIulia, pp. 42-66 (reproduced with permission). 


\section{References}

Alarcão, I., Tavares, J., (1986). Análise Psicológica e Linguística do Acto da Leitura e a sua Aplicação Pedagógica em Língua Materna e em Língua Estrangeira. Aveiro: Universidade de Aveiro.

Alderson, C. (2000). Assessing Reading. Cambridge: Cambridge University Press.

Anderson, N. (1999). Exploring Second Language Reading: Issues and Strategies. Canada: Heinle \& Heinle.

Appleman, D. (2000). Critical Encounters in High School English - Teaching Literary Theory to Adolescents. New York: Teachers College Press.

Baker, P. (2006). Using Corpora in Discourse Analysis. New York: Continuum.

Bakhtin, M. (1990). Speech Genres and Other Late Essays [1935] (trans. Vern. McGee). Austin: University of Texas Press.

Barthes, R. (1975). The Pleasure of the Text (trans. Richard Miller). New York: Hill and Wang.

Belsey, C. 2002. Critical Practice [1980]. London: Methuen.

Biber, D., Conrad, S., Reppen, R. (1998). Corpus Linguistics: Investigating Language Structure and Use. Cambridge: Cambridge University Press.

Bourne, J. (1996). English for speakers of other languages, in N. Mercer and J. Swann (Eds.), Learning English: Development and Diversity., London: The Open University, Routledge, 1, 243282.

Bourdieu, P. (1991). Language and Symbolic Power. Cambridge \& Massachusetts: Harvard University Press.

Brumfit, C., Carter, R. (1987). Literature and Language Teaching. Oxford: Oxford University Press.

Burgess, R. (1995). In the Field: An Introduction to Field Research. London: Routledge.

Byram, M. (1988). Cultural Studies in Foreign Language Education. Clevedon: Multilingual Matters - Modern Languages in Practice.

Byram, M., Grundy, P. (Eds.) (2003). Context and Culture in Language Teaching and Learning. LICE: 6. Clevedon: Multilingual Matters.

Carrell, P., Devine, J., Eskey, D. (1993). Interactive Approaches to Second Language Reading. Cambridge: Cambridge Applied Linguistics.

Carter, R., McRae, J. (1996). Language, Literature and the Learner. London: Longman.

Chambers, I. (1995). Migrancy, Culture, Identity. London and New York: Routledge.

Clark, U. (1996). An Introduction to Stylistics. Cheltenham: Stanley Thornes Publishers.

Cleary, L., Linn, M. (1993). Linguistics for Teachers. New York: McGraw Hill.

Culler, J. (1994). Structuralist Poetics - Structuralism, Linguistics and the Study of Literature. London and New York: Routledge \& Kegan Paul. 
Dillon, D., O’Brien, D., Heilman, E. (2000). Literacy research in the next millenium: from paradigms to pragmatism and practicality, in Envisioning the Future of Literacy, Reading Research Quarterly, vol. 35(1), 10-25.

Engler, B. (2000). Writing the European History of English Studies, in B. Engler and R. Haas (Eds.), European English Studies: Contributions towards the history of a discipline. European English Studies, 1-12.

Foucault, M. (1972). The Archaeology of Knowledge \& the Discourse on Language (trans. Sheridan Smith), New York: Pantheon Books.

Goodman, S., Graddol, D. (1996). Redesigning English: New Texts, New Identities. London and New York: Routledge.

Halliday, M., R. Hasan (1993). Language, Context, and Text: Aspects of Language in a SocialSemiotic Perspective [1985], Victoria: Deakin University Press.

Harmer, J. (1994). The Practice of English Language Teaching. London: Longman.

Hinson, B. (Ed.) (2000). New Directions in Reading Instruction. Delaware: International Reading Association.

Hynds, S. (1997). On the Brink: Negotiating Literature and Life with Adolescents. International Reading Association, New York: Teachers College Press.

Iser, W. (1994). The Act of Reading - A Theory of Aesthetic Response [1978]. Baltimore: The Johns Hopkins University Press.

Jakobson, R. (1971). Retrospect, in Selected Writings II (Int. by L. Waugh). Berlin: Mouton de Gruyter, 711-722.

James, A. (2008). New Englishes as post-geographic Englishes in lingua franca use: genre, interdiscursivity and late modernity, European Journal of English Studies, 12 (1), 97-112.

Jenkins, J. (2008). English as a Lingua Franca: Attitude and Identity. Oxford: O.U.P.

Karolides, N. (Ed.) (1992). Reader Response in the Classroom - Evoking and Interpreting Meaning in Literature. New Jersey: Lawrence Erlbaum Associates.

Kintsch, W., Miller, J. (1984). Readability: a view from cognitive psychology, in J. Flood (Ed.), Understanding Reading Comprehension, Newark: International Reading Association, 220-232.

Kramsch, C. (1994). Context and Culture in Language Teaching. Oxford: Oxford University Press.

Kress, G. (1997). Multimodal texts and critical discourse analysis, in Emília Pedro (Ed.), Proceedings of The First International Conference on Discourse Analysis. Edições Lisbon: Colibri, 367-383.

Langer, J. (1995). Envisioning Literature: Literary Understanding and Literature Instruction. International Reading Association, New York: Teachers College Press.

Levenston, E. (1992). The Stuff of Literature: Physical Aspects of Texts and their Relation to Literary Meaning. New York: State University of New York Press.

Mackenzie, L. (2007). English as an international language: illusions and opportunities, British and American Studies 13, 233-243. 
Melo, S., Araújo e Sá, M.-H., Pinto, S. (2006). Entre romanofilia e romanofobia: um estudo com universitários portugueses, Galenet - Plateforme de formation à l'intercompréhension en langues romanes. Retrieved March 30, 2009, from http://www.galanet.be/.

Maidment, E., Mercer, N. (1996). English in the academic world, Learning English: Development and Diversity. London: The Open University \& Routledge, 283-319.

Mercer, N., Swann, J. (1996). Learning English - Development and Diversity. London: The Open University \& Routledge.

Morgan, C., Cain, A. (2000). Foreign Language and Culture Learning from a Dialogic Perspective. Clevedon: Multilingual Matters - Modern Languages in Practice.

Micklos, J. (2001). Conference probes second language research needs, Reading Today, 19 (1), 1, 3-5.

Ong, J. (1993). Orality and Literacy: The Technologizing of the World. London: Routledge.

Partington, A. (1998). Patterns and Meanings: Using Corpora for English Language Research and Teaching. Philadelphia: John Benjamins.

Phillipson, R. (2003). English-Only Europe? Challenging Language Policy. London and New York: Routledge.

Sampson, G., D. McCarthy (Eds.) (2004). Corpus Linguistics: Readings in a Widening Discipline. London: Continuum.

Sealey, A., Carter, B. (2004). Applied Linguistics as Social Science. London and New York: Palgrave / Continuum, 128-155.

Sinclair, B. (1996), Learner autonomy and literature teaching, in Carter and McRae (Eds.), Language, Literature and the Learner. London: Addison,138-165.

Sinclair, J. (2004). Trust the Text: Language, Corpus and Discourse. London and New York: Routledge.

Swann, J. (1996). Style shifting, codeswitching, in Graddol et al. (Eds), English History, Diversity and Change. London and New York: Routledge, 301-336.

Talbot, M. (1995). Fictions at Work - Language and Social Practice in Fiction. London: Longman.

Traugott, E., Pratt, L. (1980). Linguistics for Students of Literature. San Diego: Harcourt Brace Jovanovich Publishers.

Urquhart, S., Weir, C. (1998). Reading in a Second Language: Process, Product and Practice. New York: Addison Wesley Longman.

Usher, R., Edwards, R. (1994). Postmodernism and Education. London and New York: Routledge.

Wales, K. (1997). A Dictionary of Stylistics [1989]. London: Longman.

Waugh, L, Monville-Burston, M. (Eds.) (1998). On Language: Roman Jakobson. Cambridge: Harvard University Press.

Weiss, T. (1999). Tradition and the creolization of English studies, Op. Cit. No. 2. Coimbra: Associação Portuguesa de Estudos Anglo-Americanos, 45-64.

Widdowson, H. (1996). Teaching Language as Communication [1978]. Oxford: Oxford University Press. 
Intercultural exchanges in a foreign language dimension in retrospect 179

Williams, C. (2000). Driving toward diversity, Reading Today, vol. 18(2/6).

Williams, C. (2000). IRA responds to latest NAEP Report, Reading Today, 18: 2 (48).

Woods, A., Fletcher, P., Hughes, A. (1996). Statistics in Language Studies. Cambridge: Cambridge University Press. 